\title{
REVIEW
}

\section{Slower boat speeds reduce risks to manatees}

\author{
C. Scott Calleson*, R. Kipp Frohlich \\ Florida Fish and Wildlife Conservation Commission, Imperiled Species Management Section, 620 S. Meridian Street,
} Tallahassee, Florida 32399, USA

\begin{abstract}
Collisions with boats account for approximately $25 \%$ of all documented manatee Trichechus manatus latirostris deaths in Florida. The state of Florida, as well as the US Fish and Wildlife Service and various local governments, have established boat speed limits in areas frequented by manatees as a means of reducing risks. Boat speed limits are believed to reduce risks in 3 primary ways: (1) greater reaction time for the boat operator; (2) greater reaction time for the manatee; and (3) reduced severity of injuries in the event that a manatee is hit by a boat. We review the current research and other available information that forms the conceptual basis for this risk reduction method and also examine the primary objections that have been raised against requiring slower boat speeds. The available information supports the position that reducing boat speeds in specific areas is an appropriate, reasonable, and defensible management action. Additional research on how manatees detect and respond to boats would be very useful, as would further empirical studies assessing the effectiveness of existing boat speed limits.
\end{abstract}

KEY WORDS: Florida manatee · Trichechus manatus latirostris · Waterway management Boat speed zones · Risk reduction

\section{INTRODUCTION}

Collisions with boats is the largest known source of mortality (United States Fish and Wildlife Service, USFWS, 2001), and accounts for approximately $25 \%$ of all documented manatee Trichechus manatus latirostris deaths recorded in Florida since 1976, with the annual percentage ranging from as low as $11.4 \%$ to as high as $34.2 \%$ (Florida Fish and Wildlife Conservation Commission, FWC, unpubl. data). The highest annual number of boat-related manatee deaths to date is 95, which occurred in 2002 and represented $31.1 \%$ of all documented deaths that year. Unfortunately, even though more than 1400 boat-related manatee deaths have been recorded, little definitive information is available on the types or sizes of the boats that caused these deaths or on the circumstances involved in the collisions. There are currently only 21 cases where the responsible boat is known (because the incident was reported by the boat operator or an eye witness); the earliest case was in 1978 and the most recent in 2006 (Table 1). These known incidents have involved boats ranging from 4.9 to $36.5 \mathrm{~m}$ (16 to $120 \mathrm{ft}$ ) in length, included both planing and displacement hull types, and involved boat speeds as low as $4 \mathrm{~km} \mathrm{~h}^{-1}\left(2.5\right.$ miles $\left.^{-1}\right)$ and as high as 56 to $64 \mathrm{~km} \mathrm{~h}^{-1}$ ( 35 to 40 miles $\mathrm{h}^{-1}$ ). With the exception of 2 tug and barge incidents, all of the cases that include estimated boat speeds occurred when the boats were operating at reported speeds in the 24 to $64 \mathrm{~km} \mathrm{~h}^{-1}$ (15 to 40 miles $\mathrm{h}^{-1}$ ) range.

Despite the fact that specific details are not available for the vast majority of the boat-related mortality cases, it has long been recognized that boat collisions, which can injure as well as kill manatees, represent a significant threat to these animals, a point recently reaffirmed by Haubold et al. (2006) and Runge et al. (2007). In the federal recovery plan for the manatee, the 
Table 1. Boat-related manatee deaths in Florida where the responsible vessel is known. uc: unconfirmed or unreported information. Prop: propeller; Both: propeller and impact; FWC: Florida Fish and Wildlife Conservation Commission

\begin{tabular}{|c|c|c|c|c|c|c|c|}
\hline No. & Field ID & Year & Cause & $\overline{\text { Hull type }}$ & $\begin{array}{l}\text { Vessel information } \\
\text { Vessel size } \\
\text { (m) }\end{array}$ & $\begin{array}{c}\text { Est. speed } \\
\left(\mathrm{km} \mathrm{h}^{-1}\right)\end{array}$ & Comments \\
\hline 1 & M7834 & 1978 & uc & Planing & 14 & 33 & \\
\hline 2 & M155 & 1979 & Prop & Displace & 19.8 & $\leq 9$ & $\begin{array}{l}\text { Tug boat backing out of canal, towing an } \\
\text { empty barge }\end{array}$ \\
\hline 3 & MSW081 & 1986 & Prop & Planing & 7.3 & uc & \\
\hline 4 & SWFTM8656 & 1986 & Prop & $\mathrm{uc}$ & 13.1 & uc & Hatteras ('Alfa II') \\
\hline 5 & MSW180 & 1988 & Prop & Planing & 11 & uc & \\
\hline 6 & MSW214 & 1989 & Impact & Planing & 5.5 & 56 & \\
\hline 7 & MNW9017 & 1990 & Impact & uc & 12.5 & 35 & $\begin{array}{l}\text { United States Coast Guard Cutter; possibly } \\
\text { pinned against canal bottom }\end{array}$ \\
\hline 8 & MSW9113 & 1991 & Impact & Planing & 6.1 & 32 & \\
\hline 9 & MSE9219 & 1992 & Prop & Planing & 12.2 & $\geq 40$ & Witnessed strike by an open racing style boat \\
\hline 10 & MSW9431 & 1994 & Impact & Planing & 5.3 & On plane & \\
\hline 11 & MEC9547 & 1995 & Impact & Barge & 36.6 & 4 & Crushing by barge traveling at 2 knots \\
\hline 12 & SWFTM9905 & 1999 & Prop & Planing & 13.7 & 29 & Twin $56 \mathrm{~cm}$ props \\
\hline 13 & MNW9929 & 1999 & Impact & Planing & 5.5 & $48-56$ & \\
\hline 14 & MSW0079 & 2000 & Impact & Planing & 6.7 & 40 & \\
\hline 15 & MSE0009 & 2000 & Both & Planing & 7.6 & $32-40$ & $\begin{array}{l}\text { Death mainly from impact; manatee was a } \\
161 \mathrm{~cm} \text { calf }\end{array}$ \\
\hline 16 & MEC0143 & 2001 & Prop & Planing & 17.1 & 37 & Twin 4-blade $76 \mathrm{~cm}$ props \\
\hline 17 & MEC0220 & 2002 & Impact & Planing & $5.5-6.1$ & $56-64$ & Witnessed strike \\
\hline 18 & MEC0244 & 2002 & Prop & Planing & 6.4 & $\begin{array}{l}\text { Coming up } \\
\text { on plane }\end{array}$ & $\begin{array}{l}\text { FWC Law Enforcement boat; } 39 \mathrm{~cm} \text { stainless } \\
\text { steel 3-blade prop }\end{array}$ \\
\hline 19 & MNE0514 & 2005 & Prop & uc & 12.2 & $24-32$ & Sedan Cruiser; $56 \mathrm{~cm} \mathrm{4-bladed} \mathrm{bronze} \mathrm{prop}$ \\
\hline 20 & MEC0562 & 2005 & Impact & Planing & 4.9 & On plane (uc) & Strike to head \\
\hline 21 & MNW0614 & 2006 & Impact & Planing & 8.5 & On plane (uc) & Witnessed strike \\
\hline
\end{tabular}

USFWS (2001) identified the reduction of this threat as an important task to be accomplished.

The state of Florida first began regulating boat speeds as a way of reducing risks to manatees over 25 yr ago. Various types of manatee protection zones have been established throughout Florida and the public generally understands the concept that reducing speed should reduce risk. In recent years, however, some have questioned the wisdom of slowing boats down to help protect manatees and have even suggested manatees might be at greater risk from slowmoving boats. The purpose of this paper is 2-fold: (1) to discuss the conceptual basis for slowing down boats as a means of reducing risks to manatees; and (2) to discuss the primary opposing views that have been raised against requiring slower speeds.

Section 370.12(2), Florida Statutes (FS), the Florida Manatee Sanctuary Act, states that the Florida Fish and Wildlife Conservation Commission (FWC) can 'regulate motorboat speed and operation where necessary to protect manatees from harmful collisions with motorboats and from harassment.' The FWC rules, as well as rules established by the USFWS and various local governments, involve setting maximum allowable speeds for boats. Speeds such as 'idle speed' and 'slow speed' are defined, as are various numeric limits (e.g. 25 miles $\mathrm{h}^{-1}$ etc.). Clearly, the premise of the underlying statutes and rules is that slower boat speeds are safer for manatees than faster speeds.

Limiting speed as a precautionary measure makes intuitive sense and is well established for other safety issues. For example, speed limits set on roads for automobiles vary based on the situation, with lower limits set in areas where the risk of injury or accident is higher. School zones and residential areas frequently have the lowest limits. In addition, §316.183, FS, requires drivers to reduce speed to less than the posted limit if warranted by the prevailing conditions (e.g. visibility or weather). As with automobiles, it is well established in boat traffic management and the principles of seamanship and safe boating that slowing down is the proper response in areas where there may be hazards or in congested areas. Rule 6 of the Navigation Rules requires that 'Every vessel shall at all times proceed at a safe speed so that she can take proper and effective action to avoid collision and be stopped 
within a distance appropriate to the prevailing circumstances and conditions.' (See Maloney 2003 for more information on the Navigation Rules and other aspects of seamanship. The complete set of Navigation Rules is available from the United States Coast Guard; available at: http://www.navcen.uscg.gov/mwv/navrules/ navrules.htm) As another example, in regard to boat operation in the vicinity of a divers-down flag, $\S 327.331$, FS, requires boats that approach within $91 \mathrm{~m}$ (300 ft) be operated 'no faster than is necessary to maintain headway and steerageway' (i.e. at idle speed). There have been speed limits set in various parts of Florida for boating safety purposes since at least the 1960s. Most of these zones require idle speed or slow speed.

\section{BENEFITS OF SLOWER BOAT SPEEDS}

There are 3 primary reasons why slower boat speeds are believed to reduce risks to manatees: (1) greater reaction time for the boat operator to see and avoid manatees; (2) greater reaction time for manatees to detect approaching boats and move out of the way; and (3) reduced severity of injuries in the event that a manatee is hit by a boat. Each of these reasons is discussed below.

\section{Reaction time of boat operator}

While manatees can be difficult to see in the wild, careful and observant boat operators can often spot them. One of the cardinal rules of safe boating is to keep a careful lookout. Rule 5 of the Navigation Rules requires that 'Every vessel shall at all times maintain a proper look-out by sight and hearing as well as by all available means appropriate in the prevailing circumstances and conditions so as to make a full appraisal of the situation and of the risk of collision.' When manatees breathe, their noses break the surface of the water. Hartman (1979) and Reynolds (1981) reported manatees breathing at mean intervals as short as 1 to 2 min when active, with longer intervals during lighter activity or when resting. When manatees swim, and particularly when they dive deep, their backs and tails are often visible above the surface. In addition, the flat paddle-shaped tail can make circular patterns or swirls on the water surface, which some people refer to as manatee 'tracks' or 'footprints.' Although it is easier to see manatees when the water is calm and water clarity is good, the signs that manatees are present can often be seen even when conditions are poor, since the signs occur at the surface. If a boat operator sees these signs, the operator can take appropriate action that might include slowing or stopping the vessel or altering course.

The amount of time a boat operator has to see a manatee and take appropriate avoidance action is greatly reduced as vessel speed increases. For example, a boat traveling at $48 \mathrm{~km} \mathrm{~h}^{-1}\left(30\right.$ miles $\left.\mathrm{h}^{-1}\right)$ is traveling at

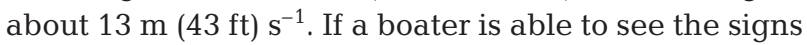
of a manatee $30 \mathrm{~m}(100 \mathrm{ft})$ in front of the boat, he will have less than $2.5 \mathrm{~s}$ to react and slow the boat and/or change course. The same boater traveling at slow speed (approximately 8 to $11 \mathrm{~km}^{-1}$ [5 to 7 miles h $\mathrm{h}^{-1}$ ] for many boats) would have about 10 to $14 \mathrm{~s}$ to react. Slow Speed zones require boats to be fully off plane and completely settled into the water and not creating an excessive wake or other hazardous condition. Because boats of different sizes and configurations can travel at different speeds while in compliance with this definition, there is no specific numeric speed assigned to Slow Speed.

\section{Reaction time of manatees}

Wild manatees have been observed and studied in their natural environments for decades. Moore (1951) and Hartman (1979) are 2 examples of pioneering scientists, both of whom describe manatees reacting to (or avoiding) boats. Perhaps because manatees have been observed avoiding boats operated at a variety of speeds for so many years, researchers have not spent a significant amount of time measuring and recording boat avoidance behaviors.

Weigle et al. (1994) performed a pilot study in Tampa Bay, Florida, to observe and quantify the responses of manatees in the wild to the approach of a $5.3 \mathrm{~m}(17.5 \mathrm{ft})$ boat at 8 to $12 \mathrm{~km} \mathrm{~h}^{-1}$ ( 5 to 7.5 miles h${ }^{-1}$ ) $32 \mathrm{~km} \mathrm{~h}^{-1}$ $\left(20\right.$ miles h$\left.^{-1}\right)$, and $48 \mathrm{~km} \mathrm{~h}^{-1}\left(30\right.$ miles $\left.\mathrm{h}^{-1}\right)$. A total of 16 boat approaches was performed. The distance from the approaching boat when a manatee first responded averaged 50 to $58 \mathrm{~m}$ (165 to $190 \mathrm{ft}$ ) and this 'response/ reaction distance' was not significantly affected by the speed at which the boat was approaching. When there was a response, the most common behavior was a slow submergence, with the next most common behavior being a movement to deeper water. Other responses included turning as the boat approached but not moving, and moving into shallower water. Bottom-resting manatees often did not respond to the approaches; however, all surface-resting manatees responded in some manner. The authors analyzed the sounds being produced by the boat at the various speeds and evaluated this information in relation to research on manatee hearing abilities. Based on this evaluation, the authors concluded the manatees could hear the boat at distances up to $100 \mathrm{~m}(330 \mathrm{ft})$. 
Nowacek et al. (2004) examined how manatees in the wild responded to approaching vessels in an area of Sarasota County, Florida. The authors found manatees 'detect and respond to approaching vessels with an apparent flight response, a response which includes movement towards deeper water. If given sufficient time, i.e., approached or passed slowly, the manatees may then be able to reach deeper water and safe depths.' The authors found manatees often began to respond when approaching vessels were $25 \mathrm{~m}$ (80 ft) or more away (with responses observed as far away as $68 \mathrm{~m}$ [225 ft]) and that whether a manatee responded was not significantly affected by the speed at which the approaching boat was traveling. This study did not attempt to address how the manatees detected the approaching boats - the manatees could have used hearing or other sensory cues. Given that underwater visibility was never more than $1.5 \mathrm{~m}$, it is very unlikely the primary detection cue was sight (D. Nowacek pers. comm. 2006).

Both of the above studies documented manatees responding to boats at distances in excess of 25 to $50 \mathrm{~m}$ (80 to $165 \mathrm{ft}$ ), regardless of the speed of the approaching boats. Keith et al. (2006) also documented manatee responses at distances of $25 \mathrm{~m}$ or more. Miksis-Olds et al. (2007) studied manatee responses to simulated vessel approaches in Sarasota County, Florida, and documented manatee responses to outboard-propelled boats approaching at idle speed $\left(8 \mathrm{~km} \mathrm{~h}^{-1}\left[5\right.\right.$ miles h$\left.\left.^{-1}\right]\right)$ and full-throttle planing (56 $\mathrm{km} \mathrm{h}^{-1}$ [35 miles $\left.\left.\mathrm{h}^{-1}\right]\right)$ as well as to personal watercraft (PWC) approaching at $40 \mathrm{~km} \mathrm{~h}^{-1}\left(25\right.$ miles $\left.\mathrm{h}^{-1}\right)$ and $64 \mathrm{~km} \mathrm{~h}^{-1}\left(40\right.$ miles $\left.\mathrm{h}^{-1}\right)$. Given the purpose and methodology of this study, the authors did not document the distances at which responses first occurred but did conclude that manatees showed the ability to distinguish between vessels approaching at different speeds and that in general manatees responded to vessel approaches by swimming toward deeper water. In addition, Mann et al. (2007) studied the ability of 2 captive manatees to localize sound and found 'strong evidence that manatees are capable of localizing sounds underwater, including those produced by boats.'

\section{Severity of blunt force injuries}

When a manatee-boat collision occurs, the severity of injuries caused by the cutting edges of a propeller is determined in part by the size (diameter) of the propeller. The speed at which a propeller is turning may also affect the resulting damage in that fast spinning propeller blades may cut through the skin more readily, while slower ones may cause more impact trauma (Lightsey et al. 2006, Rommel et al. 2007). As a result, injuries caused by the propeller blades may or may not be less severe if the boat is traveling at a slower speed. The same cannot be said for the severity of injuries caused by blunt force trauma (i.e. non-cutting injuries), which can be caused by a boat's hull, keel, rudder, lower unit (including skeg), propeller (non-cutting), or other feature that extends below the water surface (Pitchford et al. 2005, Lightsey et al. 2006, Rommel et al. 2007). The severity of blunt force injuries is directly related to the mass/weight of the boat and its speed at the time of collision, and blunt force injuries have caused more than half of the documented boat-related manatee deaths. Lightsey et al. (2006) reported that $58 \%$ of the boat-related deaths between 1993 and 2003 were the result of blunt force trauma, as compared to $32 \%$ that were caused by sharp force trauma (including propeller, skeg, and rudder cuts) and 10\% that were caused by a combination of blunt force and sharp force trauma.

The amount of impact force applied in a manateeboat collision is a function of the amount of energy supplied by the moving boat, with the transfer of that energy governed by the laws of motion and the physical parameters involved in the collision. The amount of impact energy available in a moving boat is described by the formula:

$$
\mathrm{E}=1 / 2 \text { mass } \times(\text { velocity })^{2}
$$

where 'mass' is the mass (i.e. weight) of the boat. As can be seen from the formula, doubling the speed of the boat will quadruple the amount of impact energy, while quadrupling the speed will increase the amount of energy by a factor of 16 . As an example, a boat traveling at $48 \mathrm{~km} \mathrm{~h}^{-1}\left(30\right.$ miles $\left.\mathrm{h}^{-1}\right)$ will have 36 times more energy than the same boat traveling at $8 \mathrm{~km} \mathrm{~h}^{-1}$ $\left(5\right.$ miles $\left.\mathrm{h}^{-1}\right)$. This relationship holds true regardless of the weight of the boat involved.

Blunt force trauma can cause a variety of injuries including broken and dislocated ribs, fractured skull bones and shoulder blades, and internal hemorrhaging (Wright et al. 1995, Pitchford et al. 2005, Lightsey et al. 2006). Broken and dislocated ribs can be particularly damaging as they can easily puncture the lungs or other nearby organs and muscles (Lightsey et al. 2006). Clifton (2005) examined the amount of impact energy needed to fracture manatee ribs and found that boats in

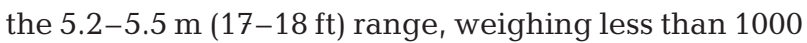
$\mathrm{kg}(2205 \mathrm{lbs})$, are capable of fracturing manatee ribs at speeds of 21-24 $\mathrm{km} \mathrm{h}^{-1}\left(13-15\right.$ miles h$\left.^{-1}\right)$. In 2006, there were 988652 recreational vessels registered in Florida (excludes 9130 vessels registered to dealers and 26593 commercial vessels), with about $50 \%$ in the 4.9 to $7.9 \mathrm{~m}$ (16 to $26 \mathrm{ft}$ ) range and about $10 \%$ greater than $7.9 \mathrm{~m}$ in length (Table 2). For vessels observed on the water, it is not uncommon for more than $65 \%$ to be in the 4.9 to 
Table 2. Recreational vessel registrations in Florida 2000-2006. Source: Florida Department of Highway Safety and Motor Vehicles (www.hsmv.state.fl.us/dmv/vslfacts.html)

\begin{tabular}{|c|c|c|c|c|c|c|c|c|}
\hline \multirow[t]{2}{*}{ Year } & \multirow[t]{2}{*}{ Canoes } & \multicolumn{6}{|c|}{ - Vessel length (m) } & \multirow[t]{2}{*}{ Total } \\
\hline & & $\begin{array}{c}<4.9 \\
(<16 \mathrm{ft})\end{array}$ & $\begin{array}{c}4.9-7.9 \\
(16-26 \mathrm{ft})\end{array}$ & $\begin{array}{c}7.9-12.2 \\
(26-40 \mathrm{ft})\end{array}$ & $\begin{array}{l}12.2-19.8 \\
(40-65 \mathrm{ft})\end{array}$ & $\begin{array}{c}19.8-33.5 \\
(65-110 \mathrm{ft})\end{array}$ & $\begin{array}{c}>33.5 \\
(>110 \mathrm{ft})\end{array}$ & \\
\hline 2000 & 4371 & 369137 & 397101 & 59103 & 10430 & 499 & 43 & 840684 \\
\hline 2001 & 5860 & 392038 & 428404 & 64710 & 10874 & 553 & 40 & 902479 \\
\hline 2002 & 6960 & 391974 & 443393 & 67816 & 11810 & 601 & 43 & 922597 \\
\hline 2003 & 7657 & 390940 & 457661 & 70944 & 12086 & 638 & 42 & 939968 \\
\hline 2004 & 8048 & 385311 & 466122 & 73395 & 12472 & 666 & 58 & 946072 \\
\hline 2005 & 8649 & 387885 & 485192 & 78028 & 13293 & 744 & 68 & 973859 \\
\hline 2006 & 9076 & 389264 & 495592 & 80300 & 13569 & 776 & 75 & 988652 \\
\hline
\end{tabular}

$7.9 \mathrm{~m}$ range, with fewer than $15 \%$ in the $4.9 \mathrm{~m}$ or less range (Shapiro 2001, Gorzelany 2002, 2004, 2005, 2006, Flamm \& Viera-Atwell 2006). While the amount of force that would be lethal in any specific instance is likely quite variable (depending on the size and health of the manatee, where and how on its body it is struck, etc.), it is clear that most boats commonly operated in Florida are capable of injuring or killing manatees even at relatively low speeds. It is also clear that boats traveling at faster speeds pack a much more powerful and potentially deadly punch than the same boats traveling at slower speeds.

\section{ARGUMENTS AGAINST REQUIRING SLOWER BOAT SPEEDS}

As stated previously, some have questioned whether requiring slower boat speeds in areas used by manatees is necessary or provides effective protection. Opposing views expressed to the FWC have been based primarily on 3 assertions: (1) manatees have a limited ability to hear boats traveling at slower speeds and, therefore, requiring slower speeds may actually increase risks; (2) requiring smaller boats to travel at slower speeds is unnecessary because it is predominately bigger boats that injure or kill manatees; and/or (3) requiring planing hull boats to operate at slower speeds creates more risk because more of the boat is below the surface of the water when the boat is offplane, thus providing more surface area that could strike a manatee and also making it necessary for a manatee to dive deeper to avoid a collision.

\section{Manatees' ability to detect boats operating at slower speeds}

The first assertion is based to a large degree on research conducted by Dr. Edmund Gerstein and others to measure a behavioral audiogram using 2 captive manatees at Lowry Park Zoo and on subsequent efforts to measure and interpret the underwater sounds produced by boats under various conditions. Gerstein et al. (1999) found the manatees they studied had a maximum hearing range of 400 to 46000 hertz (Hz), with peak sensitivity in the 16000 to $18000 \mathrm{~Hz}$ range, and that 'Given the manatees' limited low frequency hearing sensitivity, it is likely that manatees have difficulty detecting, as well as locating approaching boats from safe distances.' The authors went on to suggest that the use of a 'high frequency directional acoustic beacon would provide both directional and distance cues to the manatee and therefore might help reduce mor[t]alities associated with boats.'

Gerstein (2002) expanded on the 1999 audiogram work by collecting acoustic information for areas manatees inhabit, along with noise propagation measurements (i.e. frequencies and intensities) for various boats in these areas. By applying these measurements, in consideration of the physics of acoustic propagation in shallow water, Gerstein concludes that manatees may be least able to hear boats traveling at slower speeds because the noise produced by boats under these circumstances is often not loud enough above background ambient noise to be heard by a manatee until the boat is virtually on top of the animal. Gerstein reports the results of a simulated encounter (using measured boat noise as compared to the manatee audiogram) between an $8.2 \mathrm{~m}$ (27 ft) boat and a manatee. Gerstein concludes the manatee would be able to hear the boat when it was $198 \mathrm{~m}$ (650 ft) or $16 \mathrm{~s}$ away if the boat was traveling at $39 \mathrm{~km} \mathrm{~h}^{-1}\left(24\right.$ miles $\left.\mathrm{h}^{-1}\right)$, whereas it would not be able to hear the boat until it

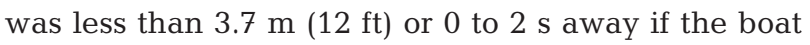
was traveling at $4.8 \mathrm{~km} \mathrm{~h}^{-1}\left(3\right.$ miles $\left.\mathrm{h}^{-1}\right)$.

In contrast to the implications of Gerstein's research, the on-water research discussed previously (Weigle et al. 1994, Nowacek et al. 2004, Keith et al. 2006, MiksisOlds et al. 2007) demonstrates that manatees are capable of responding to slowly approaching boats at distances far greater than Gerstein's research would 
suggest. When the manatees first detected these approaching boats is not known, but it could have been at even greater distances than when the manatee responses were first observed. It is possible the manatees used other sensory cues besides hearing to detect the approaching boats. However, manatees do not have very good vision (Reep \& Bonde 2006, Mann et al. 2007), so it seems unlikely sight was the primary mechanism, given the distances at which manatees responded (Nowacek et al. 2001). Another possible sensory mechanism was the detection of pressure waves (Reep \& Bonde 2006), but this also seems unlikely given the distances involved; Mann et al. (2007) provide a brief summary of prior manatee sensory system investigations and include citations to specific studies. Weigle et al. (1994) and Nowacek et al. (2004) showed the speed of the approaching boat was not a significant factor in determining when a manatee began to respond; the manatees typically responded at approximately the same distance regardless of how fast a boat was approaching. So even if manatees can hear fast boats at greater distances than slow boats, available research suggests manatees do not respond until boats are close enough for the manatee to perceive the boat as a threat or nuisance.

Gerstein is currently authorized by a federal permit to study his concept of an acoustic beacon and how manatees react to boats with a beacon as compared to those without. If the use of an acoustic beacon is found to improve a manatee's ability to detect and react to an approaching boat, it could provide an important means of reducing risks to manatees in some circumstances. However, even if a manatee's ability to detect and react to boats is improved, use of a beacon without reducing boat speeds would ignore and eliminate the other 2 reasons why slower boat speeds are beneficial, namely increased boater response time and reduced severity of blunt force injuries. Other issues related to the acoustic beacon would also need to be studied, including how manatees would respond if there was more than one boat with a beacon in the same area, whether boats with beacons would make it more difficult for manatees to detect boats without beacons in the same area, as well as whether widespread use of the beacon would have any significant adverse effects on the underwater environment as a whole (e.g. by adding additional sound to what can already be a noisy environment).

\section{Sizes of boats that injure and kill manatees}

The second rationale used against requiring slower boat speeds is based on interpretations of previous studies and on some ongoing research that involves examining the dimensions of propeller wounds on manatees and attempting to determine the approximate size of the propeller and, by association, the size class or type of the responsible boat. Because the lengths of some lethal propeller cuts on manatees are greater than could have been caused by propellers that are typically used on smaller recreational boats (i.e. $<12.2 \mathrm{~m}[40 \mathrm{ft}]$ ), some contend that many (if not most) of the manatees killed by boats are killed by large boats that are unaffected by speed zones because they are typically operated at slower speeds anyway. A common conclusion is that slower speeds should not be required, or at least that they should not be required of smaller boats, since smaller boats do not represent a significant threat.

Beck et al. (1982) examined propeller wound patterns on 43 individual manatees, 11 of which were killed as a result of propeller wounds between 1974 and 1979, and 32 of which were alive but had fresh, recent, or healing propeller injuries. The authors found that the mean length of the longest propeller wounds on the live manatees (i.e. sub-lethal cuts) was $16.4 \mathrm{~cm}$ (6.5 inches), whereas the mean length of the longest propeller wounds on the dead manatees (i.e. lethal cuts) was about $43.1 \mathrm{~cm}$ (17 inches). Given their finding that typical outboard and stern-drive boats had propellers with diameters of $38 \mathrm{~cm}$ (15 inches) or less, Beck et al. (1982) concluded that 'large boats powered mainly by inboard engines may be responsible for most of the manatee mortality attributed to propeller strikes. These vessels normally are over $7.3 \mathrm{~m}(24 \mathrm{ft})$ long, have propellers more than $38 \mathrm{~cm}$ (15 inches) in diameter, and are therefore capable of inflicting propeller wounds of the size found on dead manatees.'

Wright et al. (1995) expanded on the aforementioned study by examining lethal and healed propeller injuries on 628 dead manatees collected between 1979 and 1991. Regarding mean lengths of lethal propeller cuts versus sub-lethal cuts, the authors had findings similar to those of Beck et al. (1982). The mean length of lethal cuts (38.3 cm [15 inches]) was significantly greater than the mean lengths of sublethal cuts $(17.8 \mathrm{~cm}$ [ 7 inches $])$. The authors also examined boat and propeller characteristics and found that outboard and stern-drive boats still typically used propellers with diameters less than $38.3 \mathrm{~cm}$ (15 inches), but that diameters as large as $50.8 \mathrm{~cm}(20$ inches) were used on some high performance, sterndrive boats. Because the authors found significant overlap between the diameters of many outboard and stern-drive propellers with the diameters of propellers from inboard boats, they concluded 'the correlation of the wounds from propellers or scar dimensions with a particular size boat seems no longer useful' except in obvious cases such as deaths caused by large ships. 
The authors also noted that whereas propeller injuries were the primary cause of nearly $60 \%$ of the boatrelated deaths in the 1974 to 1979 period, propeller injuries were the primary cause in only about $40 \%$ of the cases for the 1979 to 1991 period and that impact (i.e. blunt force) injuries were responsible for $55 \%$ of the boat-related deaths.

Considerable efforts have been made in recent years to develop and further refine methods of analyzing manatee wounds caused by boats (Pitchford et al. 2005, Wood 2005, Lightsey et al. 2006). The most recent work is that of Rommel et al. (2007), which describes new forensic techniques that use the length and depth of propeller wounds and then applies these techniques to examine a subset of mortality data from the 2000 to 2004 period. Of the 396 boat-related deaths during the period, 227 had at least one identifiable propeller wound and 115 of the 227 had the information necessary to apply the technique. Although propeller diameter (and thereby general boat size category) could not be clearly identified in 30 of the cases, the authors found that boats in the 2 categories that include larger boats (greater than $12.2 \mathrm{~m}$ [40 ft] in length, including tug boats and large ships) were responsible for over twice as many of the propellercaused deaths (58 vs. 27) as boats in the 2 categories that include smaller boats (less than $12.2 \mathrm{~m}$ in length). The authors concluded 'This difference implies that for propeller-caused watercraft-related manatee mortalities - larger watercraft may be disproportionately more lethal than smaller watercraft' and that 'Interestingly, large and very large watercraft represent a very small percentage $(<2 \%)$ of the watercraft registered in Florida.' It should be noted, however, that the authors cautioned that wound length and depth measurements in moderately and badly decomposed carcasses tend to overestimate the size of propellers, and concluded that their analysis was likely significantly biased towards identifying large propellers. Additionally, the authors noted numerous other confounding factors that could bias the analysis towards both large and small watercraft, and cautioned readers who attempt to draw conclusions on vessel size.

While Rommel et al. (2007) found that a relatively high proportion of the penetrating propeller-caused boat-related deaths in recent years was caused by larger boats, it also found that smaller boats were responsible for about one-third of the propeller-caused deaths that could be attributed to a boat size category. It is also important to note that the 'larger boat' categories include boats in the 12.2 to $19.8 \mathrm{~m}$ (40 to $65 \mathrm{ft}$ ) range and that some of the boats in this category have planing hulls. Boats with planing hulls, unlike most boats with displacement hulls, are not designed to be operated only at slower speeds; some of the boats in the 12.2 to $19.8 \mathrm{~m}$ category are capable of being operated on a plane at speeds in excess of $64 \mathrm{~km} \mathrm{~h}^{-1}$ $\left(40\right.$ miles $^{-1}$ ). Therefore, at least some of the boats in this category would be affected by Slow Speed zones just as boats in the smaller boat categories would be affected.

Another important point to highlight relative to the above studies is that none of the studies considered manatees killed by blunt force injuries (i.e. not killed by cuts from the propeller or other sharp feature) or drew conclusions on the sizes or types of boats that could have been responsible for these deaths. As was noted previously, blunt force injuries can be caused by any part of a boat that extends into the water, and even small boats being operated at relatively low speeds are capable of causing significant internal injuries (Clifton 2005). Finally, the above studies only drew conclusions about the potential sizes of the boats responsible for the lethal propeller-related injuries. For the most part, no conclusions were drawn about the sizes of the boats that could have caused the sub-lethal injuries, although Beck et al. (1982) and Wright et al. (1995) both noted that the propellers used on smaller boats could have caused the sub-lethal injuries, based on the fact that the mean lengths of the these cuts were shorter than the diameters of the propellers used on smaller boats. Sub-lethal injuries likely occur much more frequently than lethal injuries, in part because of the toughness and composition of manatee skin (Lightsey et al. 2006). The number of manatees with multiple sets of healed scar patterns from previous encounters with boats suggests sub-lethal injuries are very common (O'Shea et al. 2001). At least 2 manatees have been documented to have over 50 separate sets of scar patterns from previous encounters with boats (S. Rommel pers. comm. 2006).

One final piece of information worth considering regarding boat size comes from the previously mentioned list of cases where the circumstances of lethal manatee-boat encounters are known (Table 1). Although these cases cannot be assumed to be representative of all manatee-boat encounters, they nonetheless provide valuable insights into the types of boats capable of killing manatees and the circumstances under which deaths are known to have occurred. Of the 21 cases where the responsible boat is known, 16 involved planing hull boats ranging from 4.9 to $17.1 \mathrm{~m}$ (16 to $56 \mathrm{ft}$ ) in length, one involved a tug boat, one involved a barge, and the other 3 involved unidentified types of boats in the 12.2 to $13.7 \mathrm{~m}$ (40 to $45 \mathrm{ft}$ ) range. Ten of the cases involved boats less than $7.9 \mathrm{~m}(26 \mathrm{ft})$ in length. This information clearly demonstrates that smaller boats are capable of injuring and killing manatees and that 'big' boats are not the only threat. 


\section{Increased draft of boats operating at slower speeds}

The third rationale used as a reason not to require slower boat speeds is that slower speeds cause more of a boat to be below the surface of the water and thus available to strike a manatee. The argument is essentially that requiring boats to be operated at or below Slow Speed (which requires planing-hull boats to be operated off-plane and completely settled in the water) increases the risk of collisions because manatees have to be deeper in the water to avoid the boat. Although the underlying premise of this argument is true for planing-hull boats (i.e. the draft of a planing-hull boat is less when it is operated on-plane), the difference in draft does not necessarily reduce the risk of collision. Any potential reductions in certain aspects of risk are also countered by the reduced reaction times and increased impact energy that come with higher speeds.

The amount of water a boat draws when operated off-plane varies by boat size, type, and load. Information available online (at http://boattest.com) indicates most planing-hull boats less than $9.1 \mathrm{~m}$ (30 ft) in overall length have a maximum draft of less than $0.6 \mathrm{~m}$ $(2 \mathrm{ft})$, while planing-hull boats greater than $9.1 \mathrm{~m}$ often have maximum drafts of 0.6 to $1.2 \mathrm{~m}$ ( 2 to $4 \mathrm{ft}$ ). Information on boat drafts for the most part does not specify whether the reported draft is with or without engines up, although several specify it is an 'engine up' draft. Having an outboard or stern-drive engine fully tilted down would typically add 15 to $30 \mathrm{~cm}$ (6 to 12 inches) to a boat's draft.

Information on the amount of water boats draw when operated on-plane is not as readily available as the information presented above. However, for the sake of discussion it is reasonable to assume that a boat which

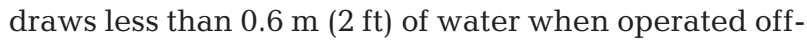
plane may have an on-plane draft of perhaps $0.3 \mathrm{~m}$ $(1 \mathrm{ft})$ or less (i.e. a reduction in draft of around $0.3 \mathrm{~m}$ ). Many boats that draw $0.6-1.2 \mathrm{~m}(2-4 \mathrm{ft})$ of water when operated off-plane will draw 0.3-0.6 m (1-2 ft) or more when operated on-plane. Based on these assumptions, on-plane boat operation results in most boats reducing their drafts by $0.6 \mathrm{~m}(2 \mathrm{ft})$ or less over what they draw off-plane.

Having a boat draw 0.3 to $0.6 \mathrm{~m}$ ( 1 to $2 \mathrm{ft}$ ) less water would reduce the likelihood of a collision with a manatee in those cases where there is enough water to allow the boat to pass completely over the manatee - but only if the manatee is already deep enough or has enough time to submerge to a safe depth. In shallow water, which is where seagrasses are most often found and where manatees consequently are often found, the reduction in draft would not always mean a collision could be avoided. Furthermore, the higher speeds needed for on-plane operation (typically $40 \mathrm{~km} \mathrm{~h}^{-1}$ [25 miles $\mathrm{h}^{-1}$ ] or more) mean the manatee and boat operator have less time to react and that the resulting injuries are more severe if a collision occurs.

As an example, assume a boat is approaching a manatee and that the boat draws $0.9 \mathrm{~m}(3 \mathrm{ft})$ when operated off-plane at $11 \mathrm{~km} \mathrm{~h}^{-1}\left(7\right.$ miles $\left.\mathrm{h}^{-1}\right)$ and $0.3 \mathrm{~m}(1 \mathrm{ft})$ when operated on-plane at $40 \mathrm{~km} \mathrm{~h}^{-1}\left(25\right.$ miles h$\left.^{-1}\right)$. If the manatee begins to respond when the boat is $25 \mathrm{~m}$ $(80 \mathrm{ft})$ away, the manatee has about $8 \mathrm{~s}$ to take avoidance actions before the boat arrives if the boat is traveling at $11 \mathrm{~km} \mathrm{~h}^{-1}$ and just over $2 \mathrm{~s}$ to respond if the boat is traveling at $40 \mathrm{~km} \mathrm{~h}^{-1}$. Since the boat draws

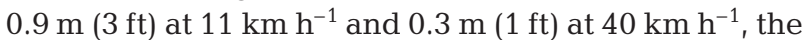
manatee needs to submerge an extra $0.6 \mathrm{~m}(2 \mathrm{ft}$ ) (total

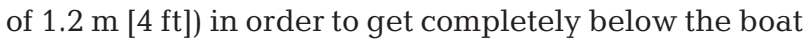
approaching at the slower speed, but it has almost $8 \mathrm{~s}$ to accomplish this task (i.e. from the surface, it needs to submerge at a rate of $\left.15 \mathrm{~cm}(0.5 \mathrm{ft}) \mathrm{s}^{-1}\right)$. Although the same boat approaching at $40 \mathrm{~km} \mathrm{~h}^{-1}\left(25 \mathrm{miles} \mathrm{h}^{-1}\right)$ only

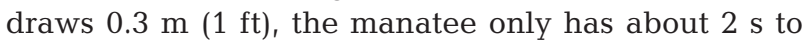
submerge the total of $0.6 \mathrm{~m}(2 \mathrm{ft})$ needed to get completely below the boat (i.e. it needs to submerge at a rate of about $30 \mathrm{~cm}(1 \mathrm{ft}) \mathrm{s}^{-1}$, or about twice as fast as needed for the boat approaching at the slower speed). If the manatee's avoidance response is to move sideways rather than submerge, the reduced draft provides virtually no positive effect, whereas a slower boat speed does.

\section{DISCUSSION AND CONCLUSIONS}

Given the fact that boat speed zones are intended to protect manatees from lethal and sub-lethal injuries and that boats of almost all types and sizes are capable of injuring and killing manatees, the available information supports the position that reducing boat speeds in specific areas is an appropriate, reasonable, and defensible management action. There are published research studies and papers and considerable field observations documenting the ability of manatees to detect and respond to boats traveling at fast and slow speeds in a variety of situations, which supports the position that slower speeds provide manatees with more time to react. Slower speeds unquestionably provide boat operators with more time to see manatees and take avoidance actions, and blunt force injuries that do occur will be less severe, and likely less lethal, when boats are traveling at slower speeds.

Additional knowledge about manatee sensory abilities and behavior would be very useful, with information on manatee hearing capabilities and how this relates to the way manatees detect and respond to approaching boats being of particular importance. An 
acoustic beacon, as well as other avoidance technologies, have potential and deserve careful study and evaluation; however, the manatee-boat collision issue is unlikely to be resolved by technological solutions alone. Boat speed limits are likely to remain an important component of manatee protection efforts.

The present paper lays out the conceptual basis for why slower boat speeds reduce risks to manatees, and thus why the FWC and others continue to use boat speed limits as a protective measure. Reducing risks on the water, however, requires more than establishing restrictions; it requires compliance with the restrictions. Many studies have assessed compliance with manatee protection boat speed limits (Tyson \& Combs 1999, Shapiro 2001, Gorzelany 2002, 2004, 2005, 2006). Although compliance levels vary significantly between sites and among boat types and sizes, overall compliance has typically been in the 50 to $75 \%$ range, with 10 to $15 \%$ of the observed boats being 'blatantly noncompliant' (e.g. planing speed through a Slow Speed zone). Substantial levels of non-compliance complicate efforts to assess the effectiveness of boat speed limits, as do other confounding factors, such as increases in the numbers of registered boats, changes in boating patterns, changes in the numbers of manatees using an area, and speed limit configurations that allow higher speeds in portions of a waterway (e.g. in marked channels). A few recent studies (Taylor et al. 2005, Keith et al. 2006, Laist \& Shaw 2006, C. Fonnesbeck unpubl. manuscript) found a positive benefit of zones; however, more empirical evidence is needed. Several 'before' and 'after' studies of boating and manatee-boat interactions are ongoing (Flamm \& Viera-Atwell 2006, Keith et al. 2006). Research on the effectiveness of boat speed limits needs to continue, as does monitoring of compliance and investigations into ways to reduce non-compliance.

Acknowledgements. We thank the many current and former employees of the Florida Fish and Wildlife Conservation Commission who reviewed preliminary drafts of this manuscript and provided very helpful comments. We particularly thank Butch Rommel and Alex Costidis, formerly at the FWC Marine Mammal Pathobiology Lab, for their detailed review and comments on the sections dealing with boat-related trauma to manatees. We also thank the 4 anonymous reviewers and the editors for their very helpful comments and suggestions.

\section{LITERATURE CITED}

Beck CA, Bonde RK, Rathbun GB (1982) Analyses of propeller wounds on manatees in Florida. J Wildl Manag 46:531-535

Clifton KB (2005) Skeletal biomechanics of the Florida manatee (Trichechus manatus latirostris). PhD dissertation, University of Florida, Gainsville, FL
Flamm RO, Viera-Atwell J (2006) Changes in vessel patterns in response to posting of a slow-speed zone with embedded 25-mph corridors in Anna Maria Sound: groundbased traffic surveys. Phase 1: boating patterns prior to posted regulations. Final Report to the Florida Fish and Wildlife Conservation Commission Office of Boating and Waterways, Tallahassee, FL

Gerstein ER (2002) Manatees, bioacoustics and boats. Am Sci 90:154-163

Gerstein ER, Gerstein L, Forsythe S, Blue J (1999) The underwater audiogram of the West Indian manatee (Trichechus manatus). J Acoust Soc Am 105:3575-3583

Gorzelany JF (2002) Evaluation of boater compliance in association with new boat speed regulations at two locations in Estero Bay. Final Report to the Florida Fish and Wildlife Conservation Commission, Tallahassee, FL

Gorzelany JF (2004) Evaluation of boater compliance with manatee speed zones along the Gulf coast of Florida. Coast Manag 32:215-226

Gorzelany JF (2005) Recreational boat traffic surveys of Broward County, Florida. Final Report to the Florida Fish and Wildlife Conservation Commission, St. Petersburg, FL

Gorzelany JF (2006) An assessment of changes in recreational boat traffic resulting from the placement of new speed zones in Lemon Bay, Florida. Final Report to the National Fish and Wildlife Foundation, Washington, DC

Hartman DS (1979) Ecology and behavior of the manatee (Trichechus manatus) in Florida. American Society of Mammalogists, Spec Publ No. 5, Pittsburgh, PA

Haubold EM, Deutsch C, Fonnesbeck C (2006) Final biological status review of the Florida manatee (Trichechus manatus latirostris). Florida Fish and Wildlife Conservation Commission, St. Petersburg, FL

Keith LW, Taylor CR, Powell JA, Frisch KJ (2006) Evaluation and monitoring of proposed manatee sanctuaries and reserves. Final Report to the United States Fish and Wildlife Service, Jacksonville, FL

Laist DW, Shaw C (2006) Preliminary evidence that boat speed restrictions reduce deaths of Florida manatees. Mar Mamm Sci 22:472-479

Lightsey JD, Rommel SA, Costidis AM, Pitchford TD (2006) Methods used during gross necropsy to determine watercraft-related mortality in the Florida manatee (Trichechus manatus latirostris). J Zoo Wildl Med 37:262-275

Maloney ES (2003) Chapman piloting \& seamanship, 64th edn. Hearst Books, New York

Mann D, Bauer G, Colbert D, Gaspard J, Reep R (2007) Sound localization abilities of the West Indian manatee. Final Report to the Florida Fish and Wildlife Conservation Commission, St. Petersburg, FL, Project FWC 03/04-28 (January 2007)

Miksis-Olds JL, Donaghay PL, Miller JH, Tyack PL, Reynolds JE III (2007) Simulated vessel approaches elicit differential responses from manatees. Mar Mamm Sci 23:629-649

Moore JC (1951) The range of the Florida manatee. Q J Fla Acad Sci 14:1-19

Nowacek DP, Buckstaff KC, Johnson MP, Wells RS (2001) Transmission loss of vessel noise in manatee environments. Final Contract Report to the Florida Fish and Wildlife Conservation Commission, St. Petersburg, FL, Contract 99023

Nowacek SM, Wells RS, Owen ECG, Speakman TR, Flamm RO, Nowacek DP (2004) Florida manatees, Trichechus manatus latirostris, respond to approaching vessels. Biol Conserv 119:517-523

O'Shea TJ, Lefebvre LW, Beck CA (2001) Florida manatees: perspectives on populations, pain, and protection. In Dier- 
auf LA, Gulland FMD (eds) CRC handbook of marine mammal medicine, 2nd edn. CRC Press, Boca Raton, FL

Pitchford TD, Rommel SA, Pitchford ME (2005) Characterizing and interpreting watercraft-related wounds in Florida manatees: a retrospective analysis of Florida manatee mortality data for evidence of deaths attributable to (very) large vessels, 1990-1999. Final Report to the United States Fish and Wildlife Service, Jacksonville, FL

Reep RL, Bonde RK (2006) The Florida manatee. University Press of Florida, Gainesville, FL

Reynolds JE III (1981) Behavior patterns in the West Indian manatee, with emphasis on feeding and diving. Fla Sci 44:233-241

Rommel SA, Costidis AM, Pitchford TD, Lightsey JD, Snyder RH, Haubold EM (2007) Forensic methods for characterizing watercraft from watercraft-induced wounds on the Florida manatee (Trichechus manatus latirostris). Mar Mamm Sci 23:110-132

Runge MC, Sanders-Reed CA, Langtimm CA, Fonnesbeck CJ (2007) A quantitative threats analysis for the Florida manatee (Trichechus manatus latirostris). US Geological Survey Open-File Report 2007-1086 (available online at: http://www.pwrc.usgs.gov/resshow/manatee/documents/ OFR2007-1086.pdf

Shapiro SL (2001) Assessing boater compliance with manatee speed zones in Florida. Final Report to the United States Fish and Wildlife Service, Jacksonville, FL. Project No. 9322-1602280

Editorial responsibility: Helene Marsh, Townsville, Queensland, Australia
Taylor CR, Powell JA, Frisch KJ (2005) Evaluation of manatee boat speed zones. Final Programmatic Report to the National Fish and Wildlife Foundation, Washington, DC. Contract No. 1999-0273-002

Tyson S, Combs L (1999) Canaveral Barge Canal boater activity and compliance study, Brevard County, Florida. Final Report to the Florida Dept. of Environmental Protection, Tallahassee, FL, and the United States Fish and Wildlife Service, Jacksonville, FL

USFWS (2001) Florida manatee recovery plan, (Trichechus manatus latirostris), third revision. US Fish and Wildlife Service, Atlanta, GA

Weigle BL, Wright IE, Huff JA (1994) Responses of manatees to an approaching boat: a pilot study. Presentation at the First International Manatee and Dugong Research Conference, Gainesville, FL, March 1994

Wood JL (2005) Repeatability of methods of propeller cut analysis using photographs of cuts and scars on carcasses and living animals. Report to the Florida Fish and Wildlife Conservation Commission, Tallahassee, FL, Discover Florida's Oceans Tag Grant \#DFO0506-02

Wright SD, Ackerman BB, Bonde RK, Beck CA, Banowetz DJ (1995) Analysis of watercraft-related mortalities of manatees in Florida, 1979-1991. In: O'Shea TJ, Ackerman BB, Percival HF (eds) Population biology of the Florida manatee. National Biological Service Information and Technology Report 1, Washington, DC, p 259-268

Submitted: June 2, 2007; Accepted: September 25, 2007 Proofs received from author(s): October 15, 2007 